\title{
Molecular characterization and technological properties of wine yeasts isolated during spontaneous fermentation of Vitis vinifera L.cv. Narince grape must grown in ancient wine making area Tokat, Anatolia
}

\author{
Zeynep Dilan Çelik ${ }^{1,2}$, Hüseyin Erten ${ }^{2}$, Merve Darici $^{2}$, and Turgut Cabaroğlu ${ }^{2, a}$ \\ ${ }^{1}$ Çukurova University, Department of Biotechnology, Adana, Turkey \\ ${ }^{2}$ Çukurova University, Agriculture Faculty, Food Engineering Dept., Adana, Turkey
}

\begin{abstract}
Narince is a native white grape variety of Vitis vinifera L grown in Tokat and produces rich and balanced wines often with a greenish yellow tint and delicate fruity flavour. Fermentation by indigenous yeasts may produce wines with complex oenological properties that are unique to specific region. In this study yeast population during alcoholic fermentation of Narince was investigated. Yeasts were identified by PCR-RFLP analysis of the 5.8 ITS rRNA region and sequence information for the D1/D2 domains of the $26 \mathrm{~S}$ gene. Eight different species belonging to nine genera were identified as: Hanseniaspora uvarum, Hansenispora guilliermondii, Pichia kluyveri, Metschnikowia spp., Pichia occidentalis, Torulaspora delbrueckii, Candida zemplinina, Lachancea thermotolerance and Saccharomyces cerevisiae. Hanseniaspora guilliermondii, Metschnikowia spp., Pichia occidentalis and Pichia kluyveri were identified only in the early stage of fermentation. Selected yeasts tested for their physiological traits, ethanol, $\mathrm{SO}_{2}$, temperature, $\mathrm{pH}$ tolerance, $\mathrm{H}_{2} \mathrm{~S}$ production, killer and enzymatic activity, fermentation rate, flocculation characteristic, foam, volatile acid and volatile compounds production. Among the yeasts, one,Lachancea thermotolerance and four Saccharomyces cerevisiae strain showed remarkable technological properties and results were compared with those obtained by using commercial starter culture.
\end{abstract}

\section{Introduction}

Vitis vinifera cv. Narince grape is one of the most important native white varieties grown in North-east Anatolia Region of Turkey. Narince produces rich and balanced wines that often have a greenish yellow tint and delicate, fruity aromas. Because of their balanced acidity, these wines are suitable for ageing and acquire a rich and complex bouquet over time $[1,2]$.

One of the important factors affecting wine quality is yeast. Grape must harbour indigenous NonSaccharomyces spp. and Saccharoyces yeasts. Many studies state that production of wines by indigenous yeasts isolated from its terroir can contribute to the regional character of wines, especially wine flavour [3-5]. On the other hand, winemakers usually prefer to use Saccharomyces $(S$.) cerevisiae strains unique to the region because those strains adapt easily to regional conditions and can readily dominate must during alcoholic fermentation [6].

Cv. Narince is the commercially important unique white wine grape variety of the Tokat region. Narince vineyards of Tokat region has remarkable historical value dating back to Hittie times civilized 4000 years ago. The wineries produced wines from cv. Narince, unfortunately, use the commercial dry yeasts instead of autochthonous indigenous yeasts. As far as it is known, there is no

a e-mail: tcabar@cu.edu.tr previous study on the molecular characterization of yeasts isolated from Narince spontaneous wine fermentations and then determination of their technological properties.

The aim of this study was to identify yeasts during spontaneous fermentation of $\mathrm{cv}$. Narince and then to determine technological properties of some selected S. cerevisiae and Non-Saccharomyces spp. yeasts.

\section{Materials and methods}

\subsection{Chemical analysis of Narince must}

Density, brix, titrable acidity, $\mathrm{OD}_{4} 20$, FAN (free amino nitrogen), reducing sugar and $\mathrm{pH}$ were measured according to the methods outlined by OIV, 2015 [7]; glucose and fructose were quantified using HPLC (LC-20AD, Shimadzu, Kyoto, Japan) [8,9].

\subsection{Sampling and Yeast Isolation}

The study was conducted in commercial vineyard located in the Tokat Region, Turkey. White grapes of cv. Narince from Tokat hand harvested, was randomly collected (undamaged and healthy grapes) in sterile plastic bags. From the sampling points approximately $10 \mathrm{~kg}$ grapes were collected and transported to the laboratory

Indigenous strains belonging to Saccharomyces and non-Saccharomyces genera were isolated from Narince grape berries and also from different stage of the

(C) The Authors, published by EDP Sciences. This is an Open Access article distributed under the terms of the Creative Commons Attribution License 4.0 (http://creativecommons.org/licenses/by/4.0/). 
spontaneous fermentation. Yeasts on Narince grape berries were isolated according to Combine (2005) [10]. At the laboratory the samples were crushed under aseptic conditions in the original plastic bags. The juice obtained $(1 \mathrm{~L})$ was transferred into sterile bottles and spontaneous fermentation was performed under controlled temperature at $18^{\circ} \mathrm{C}$. During first day after the initiation of fermentation, in the middle and at the end of fermentation, samples of must and wine, diluted in $0.1 \%$ peptonewater (decimal dilutions), were inoculated onto plates of YPD, Lysine and modified YPD agar (\% 10 ethanol, v/v and $2 \mathrm{~g} / \mathrm{L}$ photassium metabisulphite) supplemented with chloramphenicol and sodium propionate to inhibit bacteria and filamentous fungi, respectively. Plates were incubated at $28{ }^{\circ} \mathrm{C}$ for $48 \mathrm{~h}$ and about 30 yeast colonies per plate must were collected, then purified and kept at $-40{ }^{\circ} \mathrm{C}$ in $50 \%$ glycerol.

\subsection{DNA extraction and RFLP-PCR analysis}

Cell lysis for DNA extraction was performed using the InstaGene Matrix kit (Bio-Rad Laboratories, Hercules, CA) following the manufacturer's instruction. The primers used for amplification of 5.8S ITS rDNA region were ITS1 (5'- TCCGTAGGTGAACCTGCGG-3') and ITS4 (5'- TCCTCCGCTTATTGATATGC-3') [11]. The DNA amplifications were carried out in a final volume of $50 \mu \mathrm{L}$ containing $5 \mathrm{U}$ Taq DNA polymerase (MARKA), $1 \mathrm{X}$ PCR reaction buffer, $25 \mu \mathrm{M}$ dNTP, $25 \mathrm{mMMgCl}_{2}$, from each primers $100 \mu \mathrm{M}$, DNA $(50-100 \mathrm{mg} / \mu \mathrm{L})$. The PCR reaction was performed on a TC-PLUS thermal cycler (Techne, Germany). The PCR conditions were as follows: initial denaturation at $95^{\circ} \mathrm{C}$ for $5 \mathrm{~min}$; 35 cycles of denaturating at $94^{\circ} \mathrm{C}$ for $1 \mathrm{~min}$; annealing $55^{\circ} \mathrm{C}$ for $2 \mathrm{~min}$; an extension at $72^{\circ} \mathrm{C}$ for $2 \mathrm{~min}$; and a final extension step of $10 \mathrm{~min}$ at $72{ }^{\circ} \mathrm{C}$. The PCR products were subjected to restriction analysis with the restriction endonucleases Hae III, HinfI and Hha I (Thermo, USA), following the manufacturer's instructions. Amplified products and their restriction fragments were separated on $\% 1.5(\mathrm{w} / \mathrm{v})$ agarose gels at $130 \mathrm{~V}$ constant voltages for $100 \mathrm{~min}$.

\subsection{Partial 26S rRNA gene sequence analysis}

Isolates sharing identical restriction patterns were classified into groups and one or two samples were chosen as representative of each group for sequence analysis of the D1/D2 domains of the 26S rRNA gene. Amplification of the D1/D2 domains of 26S rRNA was carried out using NL1 (5' GCATATCAATAAGCGGAGGAAAAG-3') and NL4 (5'-GGTCCGTGTTTCAAGACGG-3') primers (Invitrogen, Milan, Italy), according to Kurtzman and Robnett (1998) [12], and the resulting products were commercially sequenced. The sequences obtained in FASTA format were compared with those deposited at the National Center for Biotechnology Information (NCBI), using BLAST to determine their closest known relatives. In order to confirm the identification of isolates at the species level, the sequences of the D1/D2 domain of the 26S rRNA gene were further investigated. To this purpose, the multisequence alignments among our sequences and those of type strains of their closest relatives were performed using ClustalW (Bioedit v. 7.0.9) [13,14]. The number of nucleotide differences between D1/D2 sequences of our isolates and those of their closest relative were also analysed.

\subsection{Determination of oenological properties of strains}

The ability to grow at different temperature $[15,16]$, to test the resistance to different concentration of $\mathrm{SO}_{2}$ and ethanol [17], the $\mathrm{H}_{2} \mathrm{~S}$ production [18], the killer activity and sensitivity of the strains to $\mathrm{K}_{2}$ killer toxin [14,20,21], enzymatic activity (BioMerieux), foam production $[16,22]$, fermentation rate $[3,23]$, Helm sedimentation test used to determine strains flocculation capacity [24], and the volatile acidity [7] were determined.

\subsubsection{Aroma compounds analysis}

In $15 \mathrm{~mL}$ screw-capped centrifuge tubes, containing, $4.1 \mathrm{~g}$ Ammonium sulphate, $2.7 \mathrm{Ml}$ of wine, $20 \mu \mathrm{L}$ internal standard $(140 \mu \mathrm{g} / \mathrm{ml}$ of 4-methyl -2 pentanol and 2-octanol), $6.3 \mathrm{Ml}$ water, $250 \mu \mathrm{L}$ of dichloromethane were added. The tube was shaken for $90 \mathrm{~min}$ and then centrifuged at $2500 \mathrm{rpm}$, for $10 \mathrm{~min}$, at $20^{\circ} \mathrm{C}$. Once the phases had been separated, the dichloromethane phases was recovered with a $0.5 \mathrm{~mL}$ syringe and transferred to a $0.3 \mathrm{~mL}$ viale. The extract was injected into a GC-MS under the conditions listed below. Each sample was extracted in duplicate $[25,26]$. The extracted were analysed by GC-MS-FID. The gas chromatography (GC) system consisted of an Agilent 6890 chromatograph equipped with a flame ionization detector (FID) (Wilmington, DE, USA), and an Agilent 5973-Network mass selective detector (MSD). Volatile compounds were separated on DB-Wax $(30 \mathrm{~m}$ length $\times 0.25 \mathrm{~mm}$ i.d. $\times 0.5 \mu \mathrm{m}$ thickness; J\&W Scientific Folsom, CA, USA) column. $3 \mu \mathrm{L}$ sample of extract was injected. Injector and FID detectors were set at $250{ }^{\circ} \mathrm{C}$. The flow rate of carrier gas (helium) was $3.3 \mathrm{~mL} / \mathrm{min}$. The oven temperature of the DB-Wax column was increased from $40^{\circ} \mathrm{C}$ (after $3 \mathrm{~min}$ holding) to $90^{\circ} \mathrm{C}$ at a rate of $2{ }^{\circ} \mathrm{C} / \mathrm{min}$, then at a rate of $3{ }^{\circ} \mathrm{C} / \mathrm{min}$ to $130^{\circ} \mathrm{C}$ and at a rate of $4{ }^{\circ} \mathrm{C} / \mathrm{min}$ to $240^{\circ} \mathrm{C}$ with a final hold, at $240^{\circ} \mathrm{C}$ for $12 \mathrm{~min}$. The same oven temperature programs were used for the mass selective detector. The MS (electronic impact ionization)(Agilent 5975B VL MSD) conditions were as follows: ionization energy of $70 \mathrm{eV}$, mass range $\mathrm{m} / \mathrm{z}$ of 29-350 a.m.u., scan rate of 1.0 scan $\mathrm{s}-1$, interface temperature of $250{ }^{\circ} \mathrm{C}$, and source temperature of $120^{\circ} \mathrm{C}$. The volatile compounds were identified by comparing their retention index and their mass spectra on the DB-Wax column with those of a commercial spectra database (Wiley 6, NBS $75 \mathrm{k}$ ) and of the instrument's internal library created from the previous laboratory studies. Some of the identifications were confirmed by the injection of the chemical standards into the GCMS system. Retention indices of the compounds were calculated by using an n-alkane series [27,28].

The determination of acetaldehyde and ethyl acetate was carried out by direct injection of $1 \mu \mathrm{L}$ samples into a gas chromatograph, Agilent $6890 \mathrm{~N}$ equipped with FID. Acetaldehyde and ethyl acetate separated using a Chrompack CP-WAX-57CB capillary column $(0.25 \mathrm{~mm}$ i.d. $\times 60, \mathrm{~m} \times 0.4 \mu \mathrm{m}$ film thickness) (Middelburg, The Netherlands). GC settings were as follows: injection temperature: $160^{\circ} \mathrm{C}$; oven temperature: $5 \mathrm{~min}$ at $40^{\circ} \mathrm{C}$, 
Table 1. General composition of Narince must.

\begin{tabular}{lc}
\hline General Composition & Must \\
\hline Density $\left(\mathrm{g} / \mathrm{cm}^{3}, 20^{\circ} \mathrm{C}\right)$ & $1.087 \pm 0.0$ \\
${ }^{\circ}$ Brix & $20.06 \pm 0.3$ \\
$\mathrm{pH}$ & $3.18 \pm 0.0$ \\
Titratable acidity $(\mathrm{g} / \mathrm{L}){ }^{*}$ & $5.44 \pm 0.0$ \\
Reducing sugar $(\mathrm{g} / \mathrm{L})$ & $189.9 \pm 2$ \\
OD $_{420}$ & $0.06 \pm 0.0$ \\
FAN $(\mathrm{mg} / \mathrm{L})$ & $205 \pm 0.3$ \\
Sugars $(\mathrm{g} / \boldsymbol{L})$ & \\
Glucose & $97.1 \pm 1.4$ \\
Fructose & $92.8 \pm 2.0$ \\
\hline *As tartaric acid. &
\end{tabular}

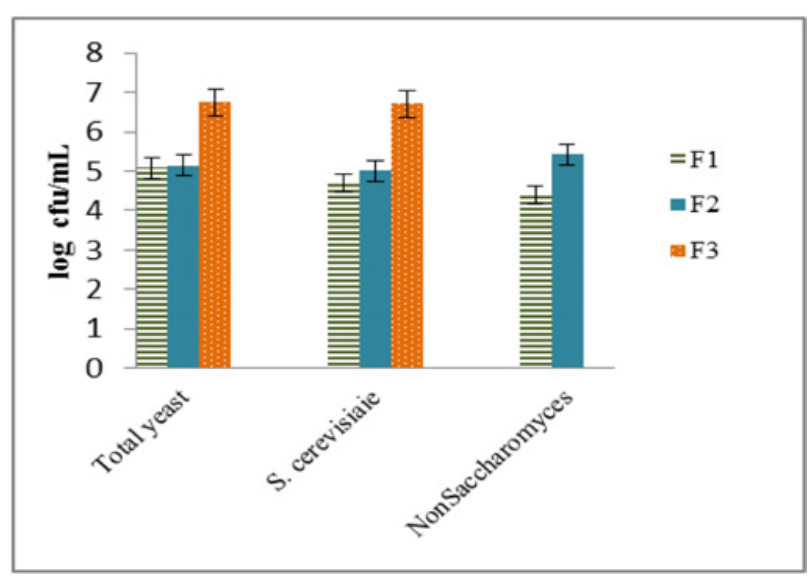

Figure 1. The viable counts from the selective and non-selective agars. F1: beginning of fermentation, F2: middle of fermentation, F3: end of fermentation.

then increased by $4{ }^{\circ} \mathrm{C}$ per minute up to $102^{\circ} \mathrm{C}$ and $2{ }^{\circ} \mathrm{C}$ per minute up to $125^{\circ} \mathrm{C}$ and hold for 5 minute and then $3{ }^{\circ} \mathrm{C}$ per minute up to $160^{\circ} \mathrm{C}, 6^{\circ} \mathrm{C}$ per minute up to 200 and finally hold 5 minute at $200^{\circ} \mathrm{C}$; carrier gas: $\mathrm{He}(1.3 \mathrm{~mL} / \mathrm{min})$; split rate: 1:50. The quantification was performed by using equation stated reference of Cabaroğlu et al. (2011) [29] with internal standard (4-methyl-2pentanol) method. Analysis was done in duplicate.

\subsection{Statistical analysis}

The results of major aroma compounds were compared by the analysis of variance (ANOVA) and principal component analysis (PCA) was carried out using XLSTAT ( 2015, Addinsoft, New York, USA). PCA tests were used to determine the significant or differences between strains.

\section{Results and discussion}

Proximate composition of Narince must is given in Table 1.

\subsection{Enumeration of yeast population}

The viable counts from the selective and non-selective agars are shown in Fig. 1. At the beginning of the spontaneous fermentation a total yeast count on YPD medium was $5 \log \mathrm{cfu} / \mathrm{mL}$ and they increased to $6.7 \mathrm{log}$ $\mathrm{cfu} / \mathrm{mL}$ at the middle of fermentation. Initial levels of total non-Saccharomyces spp. yeasts were $4.7 \log \mathrm{cfu} / \mathrm{mL}$ at the beginning and then number increased to $6 \mathrm{cfu} / \mathrm{mL}$ at the middle of fermentation and end of fermentation it was not counted.

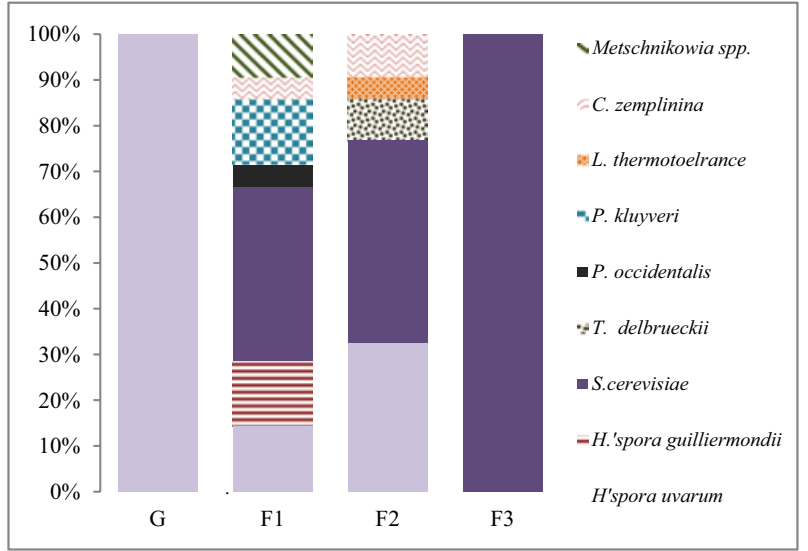

Figure 2. The diversity of yeast at grape and different fermentation stages. G: grape, F: beginning of fermentation, F2: middle of fermentation, F3: end of fermentation, $L$. thermotolerance (Lachancea thermotolerance), T. delbrueckii (Torulaspora delbrueckii), P. kluyveri (Pichia kluyveri), C. zemplinina (Candida zemplinina), P. occidentalis (Pichia occidentalis), S. cerevisiae (Saccharomyces cerevisiae), H'spora guilliermondii (Hansenispora guilliermondii), H'spora uvarum (Hanseniaspora uvarum).

\subsection{Strain identification and genetic characterization}

The diversity of yeast at grape and different fermentation stages are shown in Fig. 2. Hanseniaspora uvarum was the only yeast isolated from Narince grapes before fermentation. During fermentation, however, a diversity of $S$. cerevisiae and non-Saccharomyces spp was observed. $S$. cerevisiae and Hanseniaspora uvarum were the dominant species at the beginning and Metschnikowia spp, Pichia kluyveri, Hansenispora guilliermondii, Pichia occidentalis and Candida zemplinina were isolated with less extend at the beginning of fermentation. At the middle of fermentation, S. cerevisiae, Hanseniaspora uvarum, Candida zemplinina started to overcome yeasts and others were not isolated from middle of fermentation with the exception of Lachancea thermotolerance and Torulaspora delbrueckii which were not observed at the beginning. $S$. cerevisiae was the only isolated yeast at the end of fermentation.

The total yeasts diversion is shown in Fig. 3. Five different genera and nine different yeast species were identified. The $S$. cerevisiae yeasts represented most of the total yeast population $(49 \%)$. S. cerevisiae, followed by Hanseniaspora uvarum (23\%), Candida zemplinina and Pichia kluyveri (6\%), Torulaspora delbrueckii (5\%), Hanseniaspora guilliermondii (4\%)Lachancea thermotolerance (3\%), Metschnikowia spp. (3\%), and Pichia occidentalis (1\%).

\subsection{Technological properties of yeasts}

Eighty two yeast strains were isolated from spontaneous fermentation of Narince must. Strains were grouped according to their phylogenetic mapping (results not shown). Some of the strains belonging to different groups were examined to determine their technological properties according to the Perez-Coello et al., (1999); Labagnara (2016) $[3,30]$. The results are shown in Table 2. Twenty three strains were eliminated because of high production 
Table 2. Technological properties of remaining yeasts.

\begin{tabular}{lccccc}
\hline & 884 & 1088 & 1120 & 1333 & 1378 \\
\hline Resistance to $12 \%(\mathrm{v} / \mathrm{v})$ ethanol & + & +++ & ++ & ++ & +++ \\
\hline Resistance to $200 \mathrm{mg} / \mathrm{L} \mathrm{SO}_{2}$ & +++ & +++ & +++ & +++ & +++ \\
\hline Growth at low temperature $15^{\circ} \mathrm{C}$ & ++ & ++ & ++ & ++ & ++ \\
\hline $\mathrm{H}_{2}$ S Production & 3 :light brown & 4 :brown & 4 :brown & 3 :light brown & 4 :brown \\
\hline Killer activity & + & + & + & + & + \\
\hline Growth at Brix $30^{\circ}$ & +++ & +++ & +++ & +++ & +++ \\
\hline Foam production $\left(20^{\circ} \mathrm{C}\right)$ & $\mathrm{F} 2$ & $\mathrm{~F} 1$ & $\mathrm{~F} 0$ & $\mathrm{~F} 1$ & $\mathrm{~F} 2$ \\
\hline Foam production $\left(15^{\circ} \mathrm{C}\right)$ & $\mathrm{F} 0$ & $\mathrm{~F} 0$ & $\mathrm{~F} 0$ & $\mathrm{~F} 1$ & $\mathrm{~F} 1$ \\
\hline Fermentation rate $\left(\mathrm{g} \mathrm{CO} \mathrm{CO}_{2} / \mathrm{L} . \mathrm{h}\right)$ & $0.45 \pm 0.01$ & $0.99 \pm 0.02$ & $1.7 \pm 0.01$ & $0.8 \pm 0.02$ & $1.6 \pm 0.1$ \\
\hline Volatile acidity $(\mathrm{g} / \mathrm{L})$ & 1 & 0.72 & 1.02 & 1 & 0.8 \\
\hline Flocculation $(\%)$ & 69 & 98 & 97 & 86 & 82 \\
\hline Alkaline phospotase & 1 & 2 & 2 & 1 & 2 \\
\hline Esterase $(\mathrm{C} 4)$ & 3 & 1 & 3 & 3 & 3 \\
\hline Esterase Lipase $(\mathrm{C} 8)$ & 2 & 3 & 4 & 2 & 3 \\
\hline Arylamidase & 5 & 5 & 5 & 5 & 4 \\
\hline Valine arylamidase & 1 & 3 & 4 & 2 & 3 \\
\hline Cysteine arylamidase & 3 & 2 & 3 & 2 & 2 \\
\hline Acid phospotase & 4 & 5 & 2 & 4 & 5 \\
\hline Naphthol-AS-BI-phosphohydrolase & 3 & 3 & 3 & 2 & 3 \\
\hline$\beta-$ glucosidase & 2 & 2 & 4 & - & 3 \\
\hline
\end{tabular}

+ : low growth, ++ : medium growth, +++ : high growth, F0:0-2 mm, F1: 2-4 mm, F2: 4 and higher, 1: very low activity, 2: low activity, 3: medium activity, 4 high activity, 5 : very high activity.

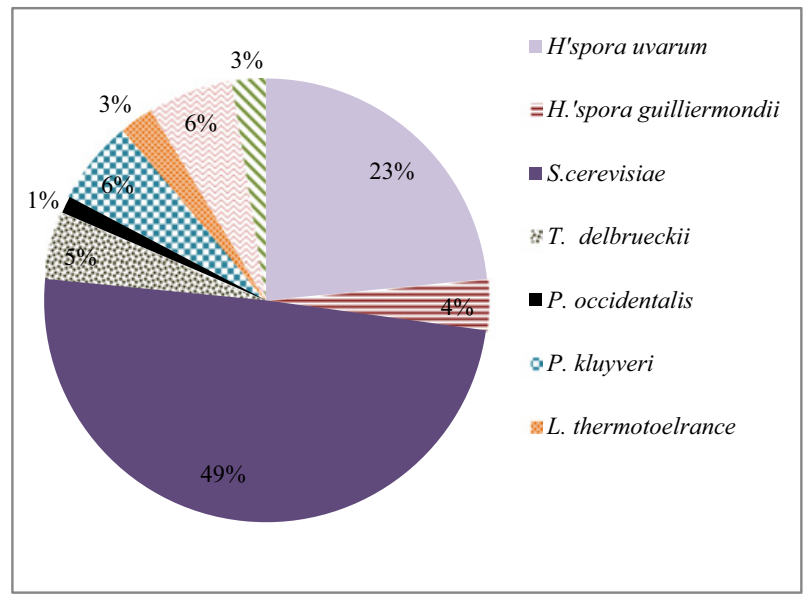

Figure 3. Total Yeast diversion. L. thermotolerance (Lachancea thermotolerance), T. delbrueckii (Torulaspora delbrueckii), P. kluyveri (Pichia kluyveri), C. zemplinina (Candida zemplinina), $P$. occidentalis (Pichia occidentalis), S. cerevisiae (Saccharomyces cerevisiae), H'spora guilliermondii (Hansenispora guilliermondii), H'spora uvarum (Hanseniaspora uvarum).

of the $\mathrm{H}_{2} \mathrm{~S}$, weak growth at different levels of ethanol, $\mathrm{SO}_{2}$ content and temperature. Of the remaining strains were subjected to determine their capacity to initiate fermentation in YPD broth containing $200 \mathrm{ppm}$ of $\mathrm{SO}_{2}$ and $12 \%(\mathrm{v} / \mathrm{v})$ alcohol at $15^{\circ} \mathrm{C}$. According to their growth, five strains were eliminated. In the next stage, killer activity, foam production, enzyme profile of the remaining strains was determined and six of them were eliminated. Remaining 4 strains of $S$. cerevisiae and 1 strain of Lachancea thermotolerance (Non-Saccharomyces) were examined for their volatile acid production, flocculation and seconder metabolites.

Table 2 shows technological properties of studied yeasts. All remaining strains showed high growth rate at
$200 \mathrm{mg} / \mathrm{L} \mathrm{SO}_{2}$ and at $30^{\circ}$ Brix. Only strain 884 was the more sensitive to the presence of ethanol at $12 \%(\mathrm{v} / \mathrm{v})$. All strains showed medium growth rate at low temperature $\left(15^{\circ} \mathrm{C}\right)$. All yeasts showed killer activity and their foam production decreased by decreasing temperature. All yeasts were produced more or less $\mathrm{H}_{2} \mathrm{~S}$. Fermentation rate of remaining yeasts were found between $0.45-1.7 \mathrm{~g}$ $\mathrm{CO}_{2}$ /L.h. Volatile acid production of strains were found between $0.7 \mathrm{~g} / \mathrm{L}-1.02 \mathrm{~g} / \mathrm{L}$. The 1120 strain produced high level of volatile acidity. The flocculation capacity was found between $68 \%-98 \%$ and the $S$. cerevisiae strain 884 was the less flocculants one. Enzymatic activities of yeasts depend on strain.

\subsection{Seconder metabolites of wines}

The results of the analysis of volatile compounds of wines fermented with the 5 selected strains and one commercial strain are shown in Table 3. Principal Component Analysis (PCA) was applied on the data set of the concentration of aroma compounds (Fig. 4).

A total of 30 aroma compounds were identified in Narince wines by GC-MS and GC/FID including 7 higher alcohols, 12 esters, 8 volatile acids, 1 lactone and 1 carbonyl compounds. Major aroma compounds ethyl acetate and acetaldehyde was calculated by GC-FID. The wines fermented with commercial strain, 884, 1088, 1120, 1333 and 1378 contained $328 \mathrm{mg} / \mathrm{L}, 276 \mathrm{mg} / \mathrm{L}, 309 \mathrm{mg} / \mathrm{L}$, $381 \mathrm{mg} / \mathrm{L}, 289 \mathrm{mg} / \mathrm{L}$ and $415 \mathrm{mg} / \mathrm{L}$ of aroma compounds respectively.

The fermentation of Narince must with the all the isolated yeasts gave different volatile profiles. Among aroma compounds higher alcohols were the most abundance compounds of wines. These compounds are formed during alcoholic fermentation. At concentrations below $300 \mathrm{mg} / \mathrm{l}$, they contribute to the desirable complexity of wine. When their concentration exceeds $400 \mathrm{mg} / \mathrm{l}$, higher alcohols are regarded as a negative quality factor [31,32]. Isoamyl 
Table 3. Aroma compounds of Narince wines fermented with different autochthonous yeasts.

\begin{tabular}{|c|c|c|c|c|c|c|c|}
\hline \multicolumn{8}{|c|}{ Aroma Compounds (mg/L) } \\
\hline Higher Alcohols & $\mathrm{C}$ & $884 * *$ & $1088 * *$ & $1120 * *$ & $1333 * *$ & 1378 ** & $\bar{F}$ \\
\hline 1-propanol & $2.36 \pm 0.02^{b}$ & $1.83 \pm 0.02^{c}$ & $2.35 \pm 0.04^{b}$ & $2.85 \pm 0.08^{a}$ & $1.91 \pm 0.01^{c}$ & $1.29 \pm 0.05^{d}$ & * \\
\hline Isobutyl alcohol & $13.14 \pm 0.09^{b}$ & $9.37 \pm 0.13^{d}$ & $13.50 \pm 0.15^{b}$ & $9.65 \pm 0.08^{c, d}$ & $9.82 \pm 0.04^{c}$ & $14.31 \pm 0.4^{a}$ & $*$ \\
\hline Isoamyl alcohol & $190.27 \pm 3.7^{b}$ & $114.31 \pm 2.5^{d}$ & $188.84 \pm 0.01^{b}$ & $112.08 \pm 4.9^{d}$ & $133.63 \pm 0.5^{c}$ & $253.51 \pm 7.5^{a}$ & $*$ \\
\hline 2,3-Butanediol & $0.56 \pm 0.04^{b}$ & $0.12 \pm 0.01^{d}$ & $0.40 \pm 0.01^{c}$ & $0.61 \pm 0.02^{b}$ & $1.52 \pm 0.06^{a}$ & $0.15 \pm 0.01^{d}$ & $*$ \\
\hline Methionol & $0.81 \pm 0.02^{b}$ & $0.25 \pm 0.01^{e}$ & $0.34 \pm 0.01^{d}$ & $0.21 \pm 0.01^{f}$ & $0.47 \pm 0.01^{c}$ & $0.89 \pm 0.05^{a}$ & $*$ \\
\hline 2-Phenylethyl alcohol & $63.28 \pm 0.7^{b}$ & $24.99 \pm 0.7^{e}$ & $47.53 \pm 0.01^{c}$ & $30.62 \pm 2.9^{d}$ & $48.63 \pm 3^{c}$ & $102.52 \pm 3.5^{a}$ & $*$ \\
\hline Tyrosol & $1.69 \pm 0.07^{a}$ & $0.32 \pm 0.01^{e}$ & $0.94 \pm 0.05^{c}$ & $0.5 \pm 0.01^{d}$ & $0.52 \pm 0.04^{d}$ & $1.12 \pm 0.07^{b}$ & $*$ \\
\hline Total & 272.11 & 151.19 & 253.9 & 156.52 & 196.5 & 373.9 & \\
\hline \multicolumn{8}{|l|}{ Esters } \\
\hline Ethyl acetate & $30.3 \pm 1.7^{d}$ & $83.39 \pm 1.4^{b}$ & $27.26 \pm 0.11^{e}$ & $184.22 \pm 0.05^{a}$ & $62.39 \pm 1.5^{c}$ & $24.14 \pm 0.7^{f}$ & $*$ \\
\hline acetate & $1.67 \pm 0.1^{b}$ & $1.37 \pm 0.06^{c}$ & $0.16 \pm 0.01^{e}$ & $0.54 \pm 0.03^{d}$ & $1.68 \pm 0.01^{b}$ & $2.42 \pm 0.07^{a}$ & $*$ \\
\hline Hexyl acetate & $0.24 \pm 0.03^{a}$ & $0.18 \pm 0.01^{c}$ & $0.05 \pm 0^{d}$ & nd & $0.21 \pm 0.01^{b}$ & $0.21 \pm 0.01^{b}$ & $*$ \\
\hline Ethyl hexaonate & $0.35 \pm 0.01^{a}$ & $0.33 \pm 0.01^{a}$ & $0.12 \pm 0.01^{b}$ & $0.15 \pm 0.0^{b}$ & $0.32 \pm 0.05^{a}$ & $0.35 \pm 0.02^{a}$ & $*$ \\
\hline Ethyl lactate & $0.20 \pm 0.03^{d}$ & $0.15 \pm 0.01^{e}$ & $0.22 \pm 0.03^{d}$ & $0.49 \pm 0.06^{a}$ & $0.3 \pm 0.01^{c}$ & $0.33 \pm 0.01^{b}$ & * \\
\hline Ethyl octaonate & $0.12 \pm 0.01^{c}$ & $0.18 \pm 0.01^{a}$ & $0.09 \pm 0^{d}$ & nd & $0.13 \pm 0.01^{c}$ & $0.16 \pm 0.01^{b}$ & $*$ \\
\hline Ethyl-3-hydroxy & $0.22 \pm 0.04^{a}$ & $0.15 \pm 0.01^{c}$ & $0.16 \pm 0.01^{b, c}$ & $0.10 \pm 0.01^{d}$ & $0.18 \pm 0.01^{b}$ & $0.18 \pm 0.01^{b}$ & $*$ \\
\hline Ethyl decanoate & $0.07 \pm 0.02^{c}$ & $0.02 \pm 0.01^{d}$ & $0.40 \pm 0.02^{a}$ & $0.13 \pm 0.01^{b}$ & $0.07 \pm 0.00^{c}$ & $0.06 \pm 0.01^{c}$ & $*$ \\
\hline Propa & $0.44 \pm 0.01^{b}$ & $0.21 \pm 0.01^{e}$ & $0.34 \pm 0.01^{c}$ & $0.55 \pm 0.0^{a}$ & $0.29 \pm 0.01^{d}$ & $0.15 \pm 0.01^{f}$ & $*$ \\
\hline 2-Phenylethyl ester & $0.27 \pm 0.04^{b}$ & $0.25 \pm{ }^{b}$ & $0.27 \pm 0.02^{b}$ & $0.06 \pm 0.0^{c}$ & $0.28 \pm 0.01^{b}$ & $0.86 \pm 0.07^{a}$ & $*$ \\
\hline Ethyl-4-hydroxybutanoate & $3.06 \pm 0.06^{c}$ & $1.15 \pm 0.02^{e}$ & $2.53 \pm 0.3^{d}$ & $5.17 \pm 0.4^{a}$ & $3.80 \pm 0.3^{b}$ & $2.46 \pm 0.09^{d}$ & $*$ \\
\hline Ethyl hydrogen suc & $0.13 \pm 0.01^{c}$ & $0.11 \pm 0.01^{d}$ & $0.07 \pm 0.00^{e}$ & $0.09 \pm 0.0^{d}$ & $0.21 \pm 0.01^{a}$ & $0.19 \pm 0.03^{b}$ & $*$ \\
\hline Total & 36.8 & 87.49 & 31.67 & 191.50 & 69.86 & 31.51 & \\
\hline \multicolumn{8}{|l|}{ Volatile acids } \\
\hline Acetic & $0.54 \pm 0.02^{c}$ & $0.62 \pm 0.01^{c}$ & $0.37 \pm 0.02^{d}$ & $1.25 \pm 0.08^{a}$ & $1.12 \pm 0.5^{b}$ & $0.60 \pm 0.02^{c}$ & $*$ \\
\hline ic acid & $0.23 \pm 0.02^{d}$ & $0.25 \pm 0.02^{c}$ & $0.32 \pm 0.01^{b}$ & $0.2 \pm 0.01^{e}$ & $0.19 \pm 0.01^{e}$ & $0.42 \pm 0.02^{a}$ & $*$ \\
\hline Butyric acid & $0.12 \pm 0.01^{b, c}$ & $0.11 \pm 0.01^{c}$ & $0.12 \pm 0.01^{c}$ & $0.14 \pm 0.01^{a, b}$ & $0.15 \pm 0.01^{a}$ & $0.13 \pm 0.01^{b, c}$ & $*$ \\
\hline Isovaleric acid & $0.62 \pm 0.01^{c}$ & $0.27 \pm 0.01^{e}$ & $0.69 \pm 0.03^{b}$ & $0.24 \pm 0.0^{f}$ & $0.34 \pm 0.01^{d}$ & $0.85 \pm 0.01^{a}$ & $*$ \\
\hline Hexanoic acid & $1.87 \pm 0.02^{d}$ & $1.86 \pm 0.02^{d}$ & $1.93 \pm 0.02^{c}$ & $0.76 \pm 0.01^{d}$ & $3.03 \pm 0.2^{a}$ & $2.31 \pm 0.04^{b}$ & $*$ \\
\hline Octanoic acid & $2.74 \pm 0.1^{b}$ & $2.42 \pm 0.02^{c}$ & $1.56 \pm 0.03^{d}$ & $0.89 \pm 0.03^{e}$ & $2.95 \pm 0.4^{a}$ & $2.85 \pm 0.01^{a, b}$ & $*$ \\
\hline Decal & $1.38 \pm 0.1^{a}$ & $0.47 \pm 0.01^{c}$ & $0.07 \pm 0.00^{d}$ & $0.50 \pm 0.01^{c}$ & $0.74 \pm 0.02^{b}$ & $0.57 \pm 0.01^{c}$ & $*$ \\
\hline Hexadecanoic acid & $0.39 \pm 0.01^{c}$ & $0.15 \pm 0.02^{e}$ & $0.1 \pm 0.01^{e}$ & $0.55 \pm 0.03^{b}$ & $0.28 \pm 0.01^{d}$ & $0.90 \pm 0.08^{a}$ & $*$ \\
\hline Total & 7.89 & 6.45 & 5.16 & 4.53 & 8.80 & 8.63 & \\
\hline \multicolumn{8}{|l|}{ Lactones } \\
\hline gamma-Butyrolactone & $0.40 \pm 0.04^{e}$ & $0.49 \pm 0.01^{d}$ & $0.34 \pm 0.01^{f}$ & $0.87 \pm 0.03^{a}$ & $0.67 \pm 0.02^{c}$ & $0.81 \pm 0.01^{b}$ & $*$ \\
\hline Total & 0.40 & 0.49 & 0.34 & 0.87 & 0.67 & 0.81 & \\
\hline \multicolumn{8}{|l|}{ Aldehydes } \\
\hline Acetaldehyde & $11.12 \pm 0.5^{e}$ & $21.35 \pm 0.7^{b}$ & $18.43 \pm 0.2^{c}$ & $27.9 \pm 0.06^{a}$ & $14.06 \pm 1^{d}$ & $9.26 \pm 0.7^{f}$ & $*$ \\
\hline Total & 11.12 & 21.35 & 18.43 & 27.9 & 14.06 & 9.26 & \\
\hline TOTAL & 328.30 & 266.97 & 309.5 & 381.32 & 289.89 & 424.11 & \\
\hline
\end{tabular}

C: wine fermented with commercial yeast strain, \pm Standard deviation, nd: not detected, F: significance at which means differ as shown using analysis of variance, ${ }^{*} \mathrm{p}<0.05$ level, **: 1120 is Lachancea thermotolerance and others are S. cerevisiae

alcohol and 2-phenylethyl alcohol were the most abundant higher alcohols in all wines and they both were found highest in wine with inoculated 1378. Odour threshold values of isoamyl alcohol and 2-phenylethyl alcohol are $30 \mathrm{mg} / \mathrm{L}$ and $10 \mathrm{mg} / \mathrm{L}$, respectively. Concentration of these compounds exceeded their threshold values in all Narince wines. 2-phenylethyl alcohol has a floral and rose like aroma and contributes positively to wine aroma [1].

Esters are an important group of volatile compounds produced by yeasts during alcoholic fermentation [31]. Ethyl acetate was the major ester compound produced in Narince wines. Aroma threshold value of ethyl acetate is $7.5 \mathrm{mg} / \mathrm{L}$ [31], and it exceeded its odour threshold value in all wines. Ethyl acetate may contribute with pleasant fruity fragrance to the general wine aroma at low concentration, whereas it contributes significantly do defect aroma at a concentration of 150-200 mg/L [32]. The wine inoculated with 1120, the ethyl acetate exceeded this value, which makes this strain unsuitable for making quality wine. Other important volatile esters, isoamyl acetate, 2-phenylethyl acetate, ethyl hexaonate and ethyl octaonate were found above their odour threshold values [31].

As indicated in Table 3, the most abundant volatile acids in Narince wines were octanoic and hexanoic acids. Similar results were found by Selli et al. (2006) [1]. The contribution of volatile acids on Narince wines cannot be considered important because their concentrations were much lower than their odour threshold values $[1,31]$.

$\gamma$-Butyrolactone was the only lactone was found in all Narince wines. This compound is found in fermented products and probably some from glutamic acid and related compounds (succinic, 2-oxoglutaric or $\gamma$-aminobutyric acids) [1,31].

The acetaldehyde is one of the most important carbonyl compound produced during fermentation and at low levels it contributes to fruity flavours, while high concentrations $(200 \mathrm{mg} / \mathrm{L})$ cause flatness in wines [32]. The concentration of acetaldehyde in Narince wines were found between 


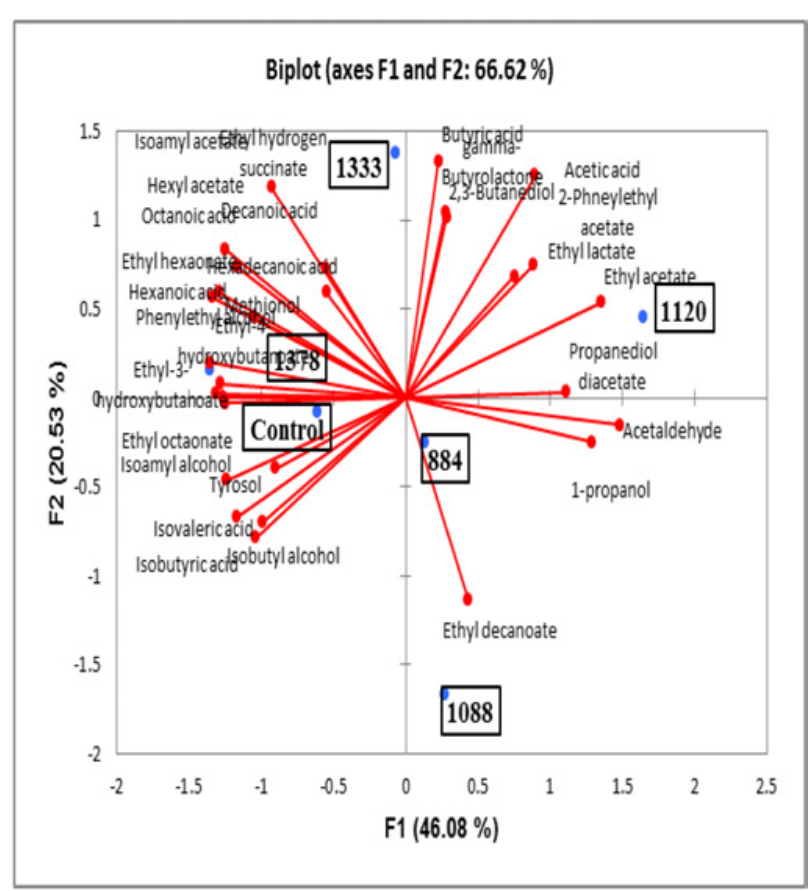

Figure 4. Principal Component Analysis of aroma compounds produced by selected yeasts.

$11 \mathrm{mg} / \mathrm{L}$ to $27 \mathrm{mg} / \mathrm{L}$. Nevertheless its concentration did not exceed its threshold values of $100 \mathrm{mg} / \mathrm{L}$ [31].

The PCA bi-plots (Fig. 4) showed the relationship between better and poorer performing yeast with regards to the aroma compounds. The PCA of aroma compounds showed that most of data explained by the first (F1) and second (F2) factors which are 46.08 and $20.53 \%$ respectively. The F1 explained $46 \%$ data variation and showed correlation 1120 and 1378. The F2 explained $20.53 \%$ of data variation and correlated with 1088 and 1333. The F3 explained $15.4 \%$ data variation and correlated with 884 and F4 explained 11\% data variation and correlated with the control. As shown in F1, 1088 well differentiated from the other yeasts due to its high content of ethyl decanoate.

\section{Conclusion}

In this study PCR-RFLP analysis of the 5.8 ITS rRNA region and sequence information for the D1/D2 domains of the $26 \mathrm{~S}$ gene were used for yeasts identification. Only one Non-Saccharomyces spp. (Hanseniaspora uvarum) identified on Narince grape surface. During spontaneous fermentation of Narince musts eight different species belonging to seven genera were identified. Of the 69 isolated native strains of $S$. cerevisiae and NonSaccharomyces from fermenting musts of Narince, only 4 S. cerevisiae and 1 Lachancea thermotoelerance (NonSaccharomyces spp.) were considered to have good enough technological properties. Moreover 1088 was the most suitable strain to make quality wine with low volatile acid and foam production, high flocculation capacity, high resistance to $12 \%(\mathrm{v} / \mathrm{v})$ ethanol and producing well balanced aroma compounds.

The authors would like to thank The Scientific and Technical Research Council of Turkey (TUBITAK) for financial support of this research (Project No. 214O173) and DİREN Wine Company for providing the grape samples.

\section{References}

[1] S. Selli, A. Canbaş, T. Cabaroğlu, H. Erten, J.P. Lepoutre, Z. Günata, Effect of skin contact on the free and bound aroma compounds of the white Vitis vinifera L cv. Narince, Food Control 17, 75-82 (2006)

[2] M.Ü. Ünal, A. Şener, Effect of harvest year on biochemical properties of Narince grape (Vitis vinifera L cv.) polyphenol oxidase, Eur. Food Resc. Tech. 238, 613-619 (2014)

[3] M.S. Perez-Coello, A.I. Briones Perez, J.F.U. Iranzo, P.J. Martin Alvarez, Characteristics of wines fermented with different $S$. cerevisiae strains isolated from the La Mancha region. Food Microbiol. 16, 563-573 (1999)

[4] M.L. R. Eder, C. Reynoso, S.C. Lauret, A.L. Rosa, Isolation and identification of the indigenous yeast population during spontaneous fermentation of Isabella (Vitis labrusca L.) grape must, Frontiers in Microbiol. 8, 532 (2017)

[5] K.P. Jemec, N. Cadez, T. Zagorc, V. Bubic, A. Zupec, P. Raspor, Yeast population dynamics in five spontaneous fermentations of Malvasia must, Food Microbiol. 18, 247-259 (2001)

[6] A. Capece, L. Granchii, S. Guerrini, S. Mangani, R. Romaniello, M. Vincenzini, P. Romano, Diversity of $S$. cerevisiae strains isolated from two Italian wine producing regions. Frontiers in Microbiol. 7, 1018 (2016)

[7] O.I.V. Compendium of international methods of wine and must analysis. International Organisation of Vine and Wine EN-2015, 1 (2015)

[8] H. Erten, Metabolism of Fructose as an Electron Acceptor by Leuconostoc mesenteroides, Process Biochemistry 33, 735-739 (1998)

[9] H. Cordier, F. Mendes, I. Vasconcelos, J.M. François "A Metabolic and Genomic Study of Engineered S. cerevisiae Strains for High Glycerol Production", Metabolic Engineering 9, 364-378 (2007)

[10] M. Combina, A. Elia, L. Mercado, C. Catania, A. Ganga, C. Martinez, Dynamics of indigenous yeast populations during spontaneous fermentation of wines from Mendoza, Argentina. Int. J. Food Microbial. 99, 237-243 (2005)

[11] B. Esteve-Zarzosa, A. Gostincar, R. Bobet, F. Uruburu, A. Querol, Selection and molecular characterization of wine yeasts isolated from the 'El Penedes area (Spain), Food Microbial. 17, 553-562 (2000)

[12] C.P. Kurtzman, C.J. Robnett, Identification and phylogeny of ascomycetous yeasts from analysis of nuclear large subunit (26S) ribosomal DNA partial sequences, Anton. Leeuw 73, 331-371 (1998)

[13] J.D.Thompson, T.J. Gibson, F. Plewniak, F. Jeanmougin, the CLUSTAL X Windows interface: flexible strategies for multiple sequence alignment aided by quality analysis tools, Nucleic Acids Res. 25, 606-615 (1997)

[14] N. Francesca, C. Carvalho, C. Sannino, M.A. Guerreiro, P.M. Almeida, L. Settani, B. Massa, J.P. 
Sampaio, G. Moschetti, Yeasts vectored by migratory birds collected in the Mediterranean island of Ustica and description of Phamffomyces usticensis f.a. sp. nov., a new species related to the cactus ecoclade, FMS Yeast Res. 14, 910-921 (2014)

[15] J.A. Regodon, F. Perez, M.E. Valdes, C. De Miguel, H. Suranska, D. Vranova, J. Omelkova, R., Vadkertiova, Monitoring of yeast population isolated during spontaneous fermentation of Moravian wine, Chemical Papers 66, 861-868 (2012)

[16] E. Nikolaou, E.H. Soufleros, E. Bouloumpasi, N. Tzanetakis, Selection of indigenous S. cerevisiae strains according to their oenological characteristics and vinification results, Food Microbiol. 23, 205-211 (2006)

[17] M. E. Parish, D.E. Carrol, Fermentation characteristics of S. cerevisiae isolates from Vitis rotundifolia grapes and musts, Am. J. Enol. Vitic 38, 45-48 (1987)

[18] M. Spiczki, P. Romano, G. Lipani, I. Miklos, Z. Antunovics, Analysis of yeasts derived from natural fermentation on a Tokaj winery, Anton. Leeuw 79, 97-105 (2001)

[19] S. Orlić, N. Očić, A, Jeromel, K. Huić, S. Redžepović, Selection of indigenous $S$. cerevisiae strains from Kutjevo wine growing area at the laboratory scale, Agriculturae Conspectus Scientificus 70, 93-97 (2005)

[20] C. J. Jacobs, J. J. Van Vuuren, Effects of Different Killer Yeasts on Wine Fermentations, Am. J. Enol. Vitic 42, 295-300 (1991)

[21] F. Özçelik, S. Dönmez, Killer yeasts and the determination of killer characters of some yeast". Doğa-Tr. J. of Biology 17, 1-4 (1993)

[22] H. Surasnka, D. Vranova, J. Omelkova, R. Vadkertiova, Monitoring of yeast population isolated during spontaneous fermentation of Moravian wine, Chemical papers 66, 861-868 (2012)
[23] J.F.U. Iranzo, A.I.B. Perez, P.M.I. Canas, Study of oenological characteristics and enzymatic activities of wine yeasts, Food Microbiol. 15, 399-406 (1998)

[24] E.V. Soares and M. Mota, Quantification of yeast flocculation. J. Inst. Brew. 103, 93-98 (1996)

[25] C. Ortega, R. Lopez, J. Cacho, V. Ferreira, Fast analysis of important wine volatile compounds development and validation of a new method based on gas chromatographic-flame ionization detection analysis of dichloromethane microextracts. J. Chrom. A 92, 3205-3214 (2001)

[26] M. Darıcı, T. Cabaroğlu, V. Ferreira, L. Lopez, Chemical and sensory characterization of the aroma of Çalkarasırose wine, Austr. J. Grape Wine Res. 20, 340-346 (2016)

[27] R. Schneider, R. Baumes, C. Bayanove, A. Razungles, Volatile Compounds Involved in the aroma of sweet of fortified wines (Vins Doux Natrurels) from Grenache Noir, J. Agric. Food Chem. 46, 3230-3237 (1998)

[28] R. Schneider, A. Razungles, C. Augier, R. Baumes, Monoterpenic and Norisoprenoidic Glycoconjugates of Vitis vinifera L. cv. Melon B. As Precursors of Odorants in Muscadet Wines, J. Chrom. A 936, 145-15 (2001)

[29] T. Cabaroğlu, M. Y1lmaztekin, Methanol and major volatile compounds of Turkish raki and effect distillate source, J.Inst. Brew. 117, 98-105 (2011)

[30] T. Labagnara, Wine yeast biodiversity during spontaneous fermentation in response to environmental stress, PhD Thesis, Pisa University, Agricultural and Veterinary Science, Tuscany 147 p. (2016)

[31] J.W. Swiegers, E.J. Bartowsky, P.A. Henschke, I.S. Pretorius, Yeast and bacterial modulation of wine aroma and flavour, Austr. J. Grape Wine Res. 11, 139-173 (2005)

[32] M. De Benedictis, G. Bleve, F. Grieco, M. Tristezza, M. Tufariello, F. Grieco, An optimized procedure for the enological selection of non-Saccharomyces starter cultures, Anton. Leeuw 99, 189-200 (2011) 